\title{
A study of female foeticide and sex determination in Jammu
}

SHASHI MANHAS AND POONAM DOGRA

Received: 30.04.2014; Revised: 30.09.2014; Accepted: 13.10.2014
See end of the paper for authors' affiliations POONAM DOGRA P.G. Department of Home Science, University of Jammu, JAMMU (J\&K) INDIA

Email: pdpoonam05@gmail.com
ABSTRACT : The present study was conducted to know the perception and awareness of family members about sex determination and female foeticide on a sample of 200 respondents through random sampling technique. Interview schedule and interview guide were used as a tool for data collection. The sample was selected from ICDS projects of Jammu district. Findings revealed that respondents were aware about sex determination tests and female foeticide through T.V, newspapers and their surroundings. Economic pressure, dowry, cost of marriage were the factors responsible for female foeticide and sex determination. Respondents were found less aware about the legal implications of female foeticide and sex determination tests.

KEY WORDS: ICDS, Female foeticide, Declining sex ratio, Sex determination tests

— HOW TO CITE THIS PAPER : Manhas, Shashi and Dogra, Poonam (2014). A study of female foeticide and sex determination in Jammu. Asian J. Home Sci., 9 (2) : 446-451. 